\title{
Difference between arterial and end-tidal carbon dioxide and adverse events after non-cardiac surgery: a historical cohort study
}

\section{Différence entre le dioxyde de carbone artériel et le dioxyde de carbone télé-expiratoire et événements indésirables après une chirurgie non cardiaque : une étude de cohorte historique}

\author{
Ryan Davis, MD (i) $\cdot$ Elizabeth Jewell, MS · Milo Engoren, MD $\cdot$ Michael Maile, MD
}

Received: 29 January 2021 / Revised: 20 July 2021 / Accepted: 22 July 2021 / Published online: 6 October 2021

(C) Canadian Anesthesiologists' Society 2021

\begin{abstract}
Purpose The difference between arterial and end-tidal partial pressure of carbon dioxide $\left(\mathrm{CCO}_{2}\right)$ is a measure of alveolar dead space, commonly evaluated intraoperatively. Given its relationship to ventilation and perfusion, $\mathrm{ACO}_{2}$ may provide prognostic information and guide clinical decisions. We hypothesized that higher $\mathrm{ACO}_{2}$ values are associated with occurrence of a composite outcome of reintubation, postoperative mechanical ventilation, or 30-day mortality in patients undergoing non-cardiac surgery.

Methods We conducted a historical cohort study of adult patients undergoing non-cardiac surgery with an arterial line at a single tertiary care medical centre. The composite outcome, identified from electronic health records, was reintubation, postoperative mechanical ventilation, or 30-day mortality. Student's $t$ test and Chi-squared test were used for univariable analysis. Logistic regression was used for multivariable analysis of the relationship of $\Delta \mathrm{CO}_{2}$ with the composite outcome.

Results A total of 19,425 patients were included in the final study population. Univariable analysis showed an association between higher mean (standard deviation [SD]) intraoperative $\triangle \mathrm{CO}_{2}$ values and the composite outcome (6.1 [5.3] vs 5.7 [4.5] $\mathrm{mm} \mathrm{Hg;P}=0.002)$. After adjusting for baseline subject characteristics, every 5-mm $\mathrm{Hg}$ increase in the $\mathrm{\Delta CO}_{2}$ was associated with a
\end{abstract}

R. Davis, MD ( $₫) \cdot$ E. Jewell, MS · M. Engoren, MD ·

M. Maile, MD

Department of Anesthesiology, University of Michigan Medical

School, 1500 E. Medical Center Dr., UH 1H247, Ann Arbor, MI

48105, USA

e-mail: ryda@med.umich.edu nearly $20 \%$ increased odds of the composite outcome (odds ratio, 1.20; 95\% confidence interval, 1.12 to 1.28; $P<$ 0.001 ).

Conclusions In this patient population, increased intraoperative $\mathrm{ACO}_{2}$ was associated with an increased odds of the composite outcome of postoperative mechanical ventilation, re-intubation, or 30-day mortality that was independent of its relationship with pre-existing pulmonary disease. Future studies are needed to determine if $\triangle \mathrm{CO}_{2}$ can be used to guide patient management and improve patient outcomes.

\section{Résumé}

Objectif La différence entre la pression partielle artérielle et télé-expiratoire en dioxyde de carbone $\left(\mathrm{ACO}_{2}\right)$ est une mesure de l'espace mort alvéolaire couramment évaluée en période peropératoire. Compte tenu de sa relation avec la ventilation et la perfusion, la $\mathrm{ACO}_{2}$ pourrait fournir des informations pronostiques et guider les décisions cliniques. Nous avons émis l'hypothèse que des valeurs de $\mathrm{CCO}_{2}$ plus élevées seraient associées à l'apparition d'un résultat composite de réintubation, de ventilation mécanique postopératoire ou de mortalité à 30 jours chez les patients bénéficiant d'une chirurgie non cardiaque.

Méthode Nous avons mené une étude de cohorte historique de patients adultes bénéficiant d'une chirurgie non cardiaque dans un seul centre médical de soins tertiaires et chez lesquels une canule artérielle était installée. Le résultat composite, identifié à partir des dossiers de santé électroniques, était la réintubation, la ventilation mécanique postopératoire ou la mortalité à 30 jours. Le test $t$ de Student et le test du chi carré ont été 
utilisés pour l'analyse univariée. La régression logistique a été utilisée pour l'analyse multivariée de la relation entre la $\mathrm{ACO}_{2}$ et le résultat composite.

Résultats Au total, 19425 patients ont été inclus dans la population finale à l'étude. L'analyse univariée a montré une association entre des valeurs peropératoires moyennes plus élevées (écart type [ET]) de $\mathrm{ACO}_{2}$ et le résultat composite $(6,1$ [5,3] vs 5,7 [4,5] $\mathrm{mmHg} ; \mathrm{P}=0,002)$. Après ajustement pour tenir compte des caractéristiques de base des sujets, chaque augmentation de $5 \mathrm{mmHg}$ de la $\mathrm{ACO}_{2}$ a été associée à une augmentation de près de $20 \%$ de la probabilité du résultat composite (rapport de cotes, 1,20; intervalle de confiance à $95 \%, 1,12$ à 1,28; $P<0,001$ ).

Conclusion Dans cette population de patients, une augmentation peropératoire de la $\mathrm{\Delta CO}_{2}$ était associée à une probabilité accrue du résultat composite de ventilation mécanique postopératoire, de réintubation ou de mortalité à 30 jours, indépendamment de sa relation avec une maladie pulmonaire préexistante. D'autres études sont nécessaires à l'avenir pour déterminer si la $\triangle \mathrm{CO}_{2}$ peut être utilisée pour guider la prise en charge des patients et améliorer les devenirs des patients.

Keywords dead space .

arterial to end-tidal carbon dioxide difference .

end-tidal carbon dioxide $\left(\mathrm{CO}_{2}\right)$.

delta carbon dioxide $\left(\mathrm{CO}_{2}\right)$

Postoperative respiratory complications are common and significant postoperative adverse events. Patients affected by complications such as pulmonary edema, postoperative respiratory failure, and pneumonia tend to have longer hospital stays, higher costs, and increased 30-day mortality. ${ }^{1-4}$ Recent studies indicate that ventilator settings contribute to postoperative pulmonary complications, even in healthy patients. ${ }^{5-8}$ These studies have focused primarily on the impact of inspiratory pressures and tidal volume (TV), with little data collected on ventilation efficiency. Dead space ventilation (VD) is affected by both lung function and perfusion, ${ }^{9}$ and its intraoperative measurement may provide prognostic information and aid in optimizing ventilation management during surgery.

Dead space is the portion of TV that does not participate in gas exchange. Total dead space $\left(\mathrm{VD}_{\text {phys }}\right)$ is composed of anatomic $\left(\mathrm{VD}_{\mathrm{ana}}\right)$ and alveolar dead space $\left(\mathrm{VD}_{\mathrm{alv}}\right)$, represented by the equation $\mathrm{VD}_{\text {phys }}=\mathrm{VD}_{\mathrm{ana}}+\mathrm{VD}_{\mathrm{alv}}$. The division between $\mathrm{VD}_{\mathrm{ana}}$ and $\mathrm{VD}_{\mathrm{alv}}$ is not a strictly anatomic division, but depends on the interface between inspired air and alveolar gas. Dead space associated with conducting airways (endotracheal tube, trachea, proximal bronchi) is described as $\mathrm{VD}_{\text {ana }}$ and dead space associated with non-perfused alveoli (distal airways) is described as $\mathrm{VD}_{\mathrm{alv}} \cdot{ }^{10}$ While $\mathrm{VD}_{\text {ana }}$ is relatively fixed in an intubated patient undergoing general anesthesia, $\mathrm{VD}_{\mathrm{alv}}$ can be influenced by perfusion (heart rate [HR], mean arterial pressure [MAP], cardiac output [CO], volume status, patient positioning), ventilation (respiratory rate [RR], $\mathrm{TV}$, positive end-expiratory pressure [PEEP]), and metabolic $\left(\mathrm{CO}_{2} \text { production }\right)^{11-13}$ variables, many of which are monitored and modified under general anesthesia.

Evaluation of $\mathrm{VD}_{\text {phys }}$ is useful in assessment and management in some clinical settings. An elevated $\mathrm{VD}_{\text {phys }}$ predicts an increased risk for mortality in acute respiratory disease syndrome (ARDS). ${ }^{14-16}$ Through its relationship to atelectasis and ventilation/perfusion (V/Q) matching, $\mathrm{VD}_{\text {phys }}$ is also useful for choosing the optimal level of PEEP in mechanically ventilated patients. ${ }^{17-19}$ As $\mathrm{VD}_{\text {ana }}$ is often a relatively fixed component, evaluation and management based on $\mathrm{VD}_{\text {phys }}$ or $\mathrm{VD}_{\mathrm{alv}}$, might be useful in other patient populations undergoing mechanical ventilation.

There are multiple ways to calculate or estimate $\mathrm{VD}_{\text {phys }}$, $\mathrm{VD}_{\mathrm{ana}}$, and $\mathrm{VD}_{\mathrm{alv}}$, but these are often not available in many clinical settings. The difference between arterial partial pressure of carbon dioxide $\left(\mathrm{PaCO}_{2}\right)$ and partial pressure of end-tidal $\mathrm{CO}_{2}\left(\mathrm{PetCO}_{2}\right), \Delta \mathrm{CO}_{2}$, is one of the most readily available methods to estimate $\mathrm{VD}_{\mathrm{alv}}$ as the difference between these two values is attributed primarily to $\mathrm{VD}_{\text {alv. }}{ }^{13,20-28}$ Increased $\Delta \mathrm{CO}_{2}$ has been associated with poor outcomes in trauma ${ }^{29}$ and critically ill patients requiring major surgery. ${ }^{13}$

The objective of this study was to evaluate if $\Delta \mathrm{CO}_{2}$ is independently associated with worse outcomes in patients undergoing non-cardiac surgery. We hypothesized that, in patients undergoing general anesthesia, greater $\Delta \mathrm{CO}_{2}$ is associated with an increased odds of the postoperative composite outcome of postoperative mechanical ventilation, re-intubation, or 30-day mortality.

\section{Methods}

Following approval from the Institutional Review Board, we conducted a historical cohort study at University of Michigan Medical Center (Ann Arbor, MI, USA); the requirement for patient consent was waived. We queried the electronic anesthesia records for all adult cases from 23 July 2009 to 31 January 2019 for which general endotracheal anesthesia was performed and at least one arterial blood gas (ABG) was recorded during the procedure. Exclusion criteria were an American Society of Anesthesiology (ASA) Physical Status classification of 
VI, preoperative mechanical ventilation, sodium bicarbonate administration within 15 min prior to $A B G$ measurement, cardiopulmonary bypass or extracorporeal membrane oxygenation, absent $\mathrm{PetCO}_{2}$ or $\mathrm{PaCO}_{2}$ data, or intraoperative one-lung ventilation.

\section{Patient and perioperative data}

Demographic information was collected from the preoperative history and physical documentation. This comprised age, sex, height, weight (actual and ideal), body mass index (BMI), ASA Physical Status score, smoking status (current or former), chronic obstructive pulmonary disease (COPD), and asthma. Preoperative values for albumin, blood urea nitrogen, creatinine, and peripheral oxygen saturation $\left(\mathrm{SpO}_{2}\right)$ were obtained. Creatinine clearance was calculated using the Cockcroft-Gault formula. Procedure variables included (i) type, (ii) duration, and (iii) emergent $v s$ elective procedure. Other intraoperative variables were the total transfusion requirement including volume of packed red blood cells, fresh frozen plasma, platelets, and cryoprecipitate; estimated blood loss; total crystalloid administration; and grams of albumin administered.

Blood gas, ventilator, and hemodynamic data

For all patients, the first $\mathrm{ABG}$ obtained in the operating room after induction of general anesthesia was utilized in our analysis and $\mathrm{pH}, \mathrm{PaCO}_{2}$, arterial partial pressure of oxygen $\left(\mathrm{PaO}_{2}\right)$, and arterial oxygen saturation $\left(\mathrm{SaO}_{2}\right)$ were collected. Ventilator parameters (TV, RR, minute ventilation, pressure support, peak airway pressure, PEEP, and fraction of inspired oxygen), hemodynamic data (HR and MAP), and $\mathrm{PetCO}_{2}$ were collected for the ten-minute epoch surrounding the $\mathrm{ABG}$ time and the median values were utilized in the analysis.

\section{Outcome}

Our study outcome was a composite of the postoperative complications, postoperative mechanical ventilation, reintubation, or mortality, as identified from the electronic health record (EHR). Postoperative mechanical ventilation was defined as any patient who required mechanical ventilation after the procedure for any duration not associated with another procedure. We defined reintubation as a period of time in the EHR without receipt of mechanical ventilation subsequently followed by the documented presence of mechanical ventilation. Mortality was included as an outcome since it would act to censor future pulmonary complications. Patients were assumed to be alive at 30 days unless noted to be deceased in the medical record.

\section{Statistics}

We calculated descriptive statistics for each variable. Continuous variables that were normally distributed were presented as mean (standard deviation [SD]). Continuous variables that were non-normally distributed were summarized as median [interquartile range (IQR)]. Categorical variables were summarized using counts and proportions.

Preoperative characteristics and $\Delta \mathrm{CO}_{2}$ were compared between those with and without the composite outcome using Chi square tests for categorical variables and $t$ tests or Mann-Whitney $U$ tests for continuous variables. Multivariable logistic regression models were generated to evaluate whether $\Delta \mathrm{CO}_{2}$ was associated with the composite outcome while adjusting for other patient and surgical factors based on clinical and statistical significance. For entry into the model, we chose clinically relevant variables that were selected by two anesthesiologists based on the literature. Additionally, we considered variables with standardized differences greater than 0.2 using Cohen's d. We also collapsed several variables into one variable, or chose a representative variable from a group, when the groups of variables were similar or highly correlated $(\rho>0.8)$. Upon constructing the multivariable model, we removed, collapsed, or grouped variables with variance inflation factors $>2.5$.

For each of the continuous variables included in the model (age, creatinine clearance, preoperative albumin, total albumin, case duration, total volume blood products, percent inspired oxygen, TV, RR, MAP, HR, and $\Delta \mathrm{CO}_{2}$ ), the following potential transformations were considered: $\mathrm{X}^{-2}, \mathrm{X}^{-1}, \mathrm{X}^{-0.5}, \ln (\mathrm{X}), \mathrm{X}^{0.5}, \mathrm{X}^{1}$, and $\mathrm{X}^{2}$. The continuous variables were binned and plotted as the proportion within each bin with the outcome. Variables with values of zero were shifted by one or one plus their minimum to use all the listed transformations. Univariate regressions with the composite outcome as the outcome and each transformation of each continuous variable were then used to predict values at the median of the bins and plot the predicted outcome for the transformation. These transformations were inspected visually and used to determine that no non-linear terms were necessary.

Additionally, all variables that were significant predictors in the initial multivariable model were also considered for interactions with the primary predictor, $\Delta \mathrm{CO}_{2}$. Each significantly associated variable was centred and an interaction between it and $\Delta \mathrm{CO}_{2}$ was added individually to the initial full regression. All interactions that were significant individually were used together in a 
full regression. Interactions that were not significant at a level of $P<0.05$ in this new full regression were removed. Even though multiple interactions remaining in the model had $P<0.05$, most interaction terms had a small magnitude of association with the outcome, none changed the direction of the relationship between $\Delta \mathrm{CO}_{2}$ and the primary outcome, and none of the variables were conceptually thought to have a multiplicative effect for any of the variables with the $\Delta \mathrm{CO}_{2}$. Based on this, none of the interactions were added to the final, clinically relevant model.

Akaike Information Criteria, Bayes Information Criteria, -2 $\log$ likelihood, and area under the receiver operating characteristic curve $(95 \%$ confidence interval [CI]) were used to evaluate the model. $P$ values $<0.05$ and CIs excluding 1 were considered statistically significant. Analyses were performed in $\mathrm{R}$ version 3.6.2 (R Core Team, $\mathrm{R}$ Foundation for Statistical Computing, Vienna, Austria).

\section{Results}

After excluding patients with missing data or data concerning for errant manual entry, 19,425 patients remained for analysis (Fig. 1). The mean (SD) time from anesthesia start to ABG was 73 (26) min. In our patient population, $15 \%(n=2,830)$ had COPD, $10 \%(n=1,951)$ had asthma, and $7 \%(n=1,274)$ were on supplemental oxygen preoperatively (Table 1 ). The mean values for $\mathrm{PaCO}_{2}$ and $\mathrm{PetCO}_{2}$ were 40.2 (5.8) $\mathrm{mm} \mathrm{Hg}$ and 34.3 (4.0) $\mathrm{mm} \mathrm{Hg}$, respectively, with a mean $\Delta \mathrm{CO}_{2}$ of $5.8(4.6) \mathrm{mm}$ Hg. A total of 3,006 patients (16\%) had the composite outcome: $85(0.4 \%)$ required postoperative re-intubation, $2,769(14 \%)$ required postoperative mechanical ventilation, and $452(2 \%)$ had 30-day mortality.

Preoperative and intraoperative variables and outcomes

Many of the evaluated variables were significantly different between groups of patients who did and did not experience the composite outcome (Table 2). Notably, patients who had the composite outcome were more likely to use preoperative supplemental oxygen (19\% vs $4 \% ; P<$ $0.001)$ and have COPD (17\% vs $14 \% ; P<0.001)$, and less likely to have asthma ( $8 \%$ vs $10 \% ; P<0.001)$. Similar smoking rates $(55 \%$ vs $55 \% ; P=0.386)$ were present in each cohort. Patients who had the composite outcome had a significantly higher mean (SD) $\Delta \mathrm{CO}_{2}(6.1$ [5.3] vs 5.7 [4.5] $\mathrm{mm} \mathrm{Hg} ; P=0.002$ ).

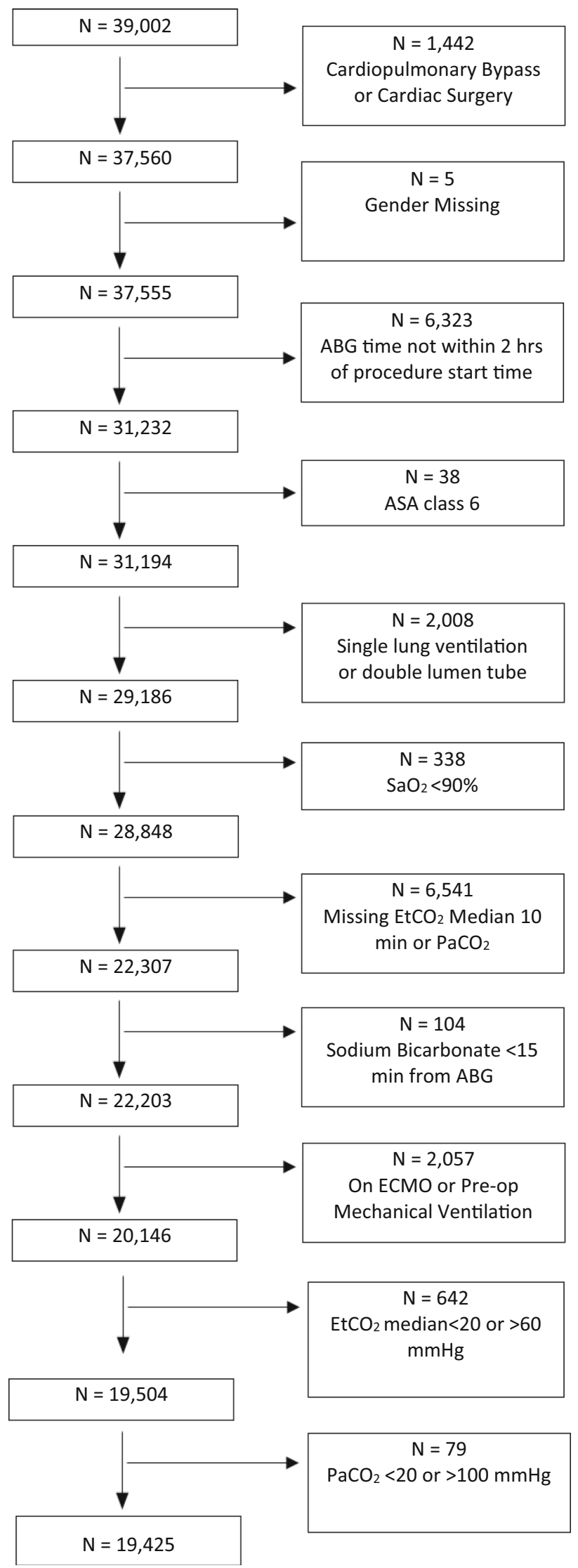


4Fig. 1 Exclusion criteria: Using initial query parameters, information for 39,002 patients were included. Patients were excluded based on pre-determined exclusion criteria. After initial exclusions, box plots of patient data were reviewed, and outliers were eliminated if data were determined to be entered in error (venous blood gas charted as arterial) or unlikely based on known physiologic variables. Ultimately, 19,425 patients were included in the final analysis.

\section{Multivariable regressions}

After adjusting for other factors, $\Delta \mathrm{CO}_{2}$ was associated with an increased occurrence of re-intubation, postoperative mechanical ventilation, or 30-day mortality (Table 3). In our regression, every $5-\mathrm{mm} \mathrm{Hg}$ increase in the $\Delta \mathrm{CO}_{2}$ was associated with a nearly $20 \%$ increased odds of the composite outcome (odds ratio [OR], 1.20; 95\% CI, 1.12 to $1.28 ; P<0.001)$. For our multivariable regression, at $\Delta \mathrm{CO}_{2}=0$, the median [IQR] risk of re-intubation, postoperative mechanical ventilation, or 30-day mortality was $9.2[7.9-10.5] \%$, at $\Delta \mathrm{CO}_{2}=5 \mathrm{~mm} \mathrm{Hg}$, the risk was 10.8 [9.5-12.2]\%, and at $\Delta \mathrm{CO}_{2}=10 \mathrm{~mm} \mathrm{Hg}$, the risk was $12.7[11.0-14.4] \%$. For the rare patient with $\Delta \mathrm{CO}_{2}=20$ $\mathrm{mm} \mathrm{Hg}$, the risk was 17.2 [13.8-20.6]\% (Fig. 2).

Several other variables were independently associated with the composite outcome (Table 3). The use of preoperative supplemental oxygen was associated with the composite outcome (OR, 2.37; 95\% CI, 1.97 to 2.84; $P<0.001$ ), while higher albumin levels were associated with a decrease in the incidence of the composite outcome (OR, 0.53 ; $95 \%$ CI, 0.48 to $0.58 ; P<0.001$ per $\mathrm{g} \cdot \mathrm{dL}^{-1}$ ). Chronic obstructive pulmonary disease was not associated with re-intubation, postoperative mechanical ventilation, or 30-day mortality (OR, 1.16; 95\% CI, 0.99 to $1.36 ; P=$ 0.06). The model had good discrimination ( $\mathrm{C}$ statistic, $0.87 ; 95 \% \mathrm{CI}, 0.86$ to 0.88$)$.

\section{Discussion}

In this historical cohort study, we found that increased $\Delta \mathrm{CO}_{2}$ was associated with an increase in the composite outcome of postoperative mechanical ventilation, reintubation, or 30-day mortality in patients undergoing general anesthesia for a non-cardiac surgical procedure. This relationship remained significant even when we adjusted for other relevant pre-existing clinical factors, including COPD, preoperative oxygen use, dialysis, and age. Since the magnitude of association for a $5 \mathrm{~mm} \mathrm{Hg}$ of change is nearly $20 \%$, even relatively small changes in $\Delta \mathrm{CO}_{2}$ produce clinically important changes to the risk of the composite outcome. For a patient with a $\Delta \mathrm{CO}_{2}$ of $2-4$ $\mathrm{mm} \mathrm{Hg}$, consistent with normal healthy levels, the median
[IQR] predicted risk of pulmonary complications or death in this patient population was between 9.9 [9.6-10.1]\% and $10.5[10.1-11.2] \%$. For a $\Delta \mathrm{CO}_{2}$ of 10,15 , and $20 \mathrm{~mm} \mathrm{Hg}$, the risk increased to 12.7 [ 11.0-14.4]\%, 14.8 [ 12.9-17.1]\%, and 17.2 [13.8-20.6]\%, respectively.

The magnitude of $\Delta \mathrm{CO}_{2}$ is affected by both ventilated but unperfused alveoli (true dead space) and alveoli with high ventilation/perfusion ratios (V/Q inequality). Shunt (perfusion without ventilation) will cause a small increase in $\Delta \mathrm{CO}_{2}$ by raising the $\mathrm{PaCO}_{2}$ as mixed venous blood, which is higher in $\mathrm{PCO}_{2}$, crosses the pulmonary circulation and mixes with the systemic arterial circulation. True dead space and V/Q inequality are markers of disease severity and increase with COPD severity or low $\mathrm{CO}$ states. $\Delta \mathrm{CO}_{2}$ is also influenced by dynamic, modifiable, and clinically important variables of ventilation (RR, TV, PEEP), perfusion (HR, MAP, CO, volume status, patient positioning), and metabolism ( $\mathrm{CO}_{2}$ production). ${ }^{11-13,30}$ Some of these are under the control of the anesthesiologist, and studies should be conducted to determine how anesthesiologists' manipulation of these parameters affects both $\Delta \mathrm{CO}_{2}$, and more importantly, patient outcome.

Clinically, $\Delta \mathrm{CO}_{2}$ has been utilized as a surrogate for $\mathrm{VD}_{\mathrm{alv}}$, primarily in the intensive care unit, where levels correlate with the amount of $\mathrm{VD}_{\mathrm{alv}}{ }^{31}$ In addition, $\Delta \mathrm{CO}_{2}$ has been shown to correlate with disease severity in ARDS patients, with a higher $\Delta \mathrm{CO}_{2}$ being associated with more severe $\mathrm{ARDS}^{32}$ and with death. ${ }^{33}$ Similarly, elevated $\Delta \mathrm{CO}_{2}$ in patients who have survived cardiac arrest is associated with high hospital mortality. ${ }^{34}$ Nevertheless, use of $\Delta \mathrm{CO}_{2}$ as an intraoperative prognostic measure is less common but is supported by our findings.

Tyburski et al. studied 501 trauma patients undergoing emergency surgery. In patients who died ( $n=147$ [29\%]), $\Delta \mathrm{CO}_{2}$ was higher at all three time points evaluated (initial, post-resuscitation, and final). In those who died, lower values were predictive of longer survival with a final mean (SD) $\Delta \mathrm{CO}_{2}$ of 22.25 (14.32) $\mathrm{mm} \mathrm{Hg}$ in patients who died intraoperatively, $19.96(14.91) \mathrm{mm} \mathrm{Hg}$ in patients who died within $24 \mathrm{hr}$ after surgery, and 10.90 (10.13) $\mathrm{mm} \mathrm{Hg}$ in patients who died after $24 \mathrm{hr}$ but before hospital discharge. Survivors had a $\Delta \mathrm{CO}_{2}$ of 7.37 (6.30) $\mathrm{mm} \mathrm{Hg}$ (all $P<0.006$ compared with non-survivors). ${ }^{29}$ In another study of critically ill or injured patients requiring major surgery with $41 \%$ mortality, Domsky et al. found highest mortality rates in patient with the highest $\Delta \mathrm{CO}_{2}$, and highest estimated $\mathrm{VD}_{\mathrm{alv}}$ fraction. ${ }^{13}$ Our study is in agreement with these two studies. While these studies are limited to trauma and critically ill surgery patients, our study is more generalizable as it includes a large variety of non-cardiac operations. To our knowledge, our study is the first large study showing that increased $\Delta \mathrm{CO}_{2}$ is associated with our 
Table 1 Patient and demographic characteristics

\begin{tabular}{|c|c|c|c|c|}
\hline \multirow{2}{*}{$\overline{\text { Male }}$} & & \multirow{2}{*}{$\frac{\text { Total } N}{19,355}$} & \multirow{2}{*}{$\frac{n}{10,981}$} & \multirow{2}{*}{$\frac{(\%)}{(56.7 \%)}$} \\
\hline & & & & \\
\hline \multicolumn{5}{|c|}{ Comorbidities } \\
\hline \multicolumn{2}{|c|}{ Supplemental oxygen } & 19,355 & 1,274 & $(6.6 \%)$ \\
\hline \multicolumn{2}{|c|}{ Current or former smoker } & 19,355 & 10,669 & $(55.2 \%)$ \\
\hline \multicolumn{2}{|c|}{ COPD } & 19,355 & 2,830 & $(14.6 \%)$ \\
\hline \multicolumn{2}{|c|}{ Asthma } & 19,335 & 1,951 & $(10.1 \%)$ \\
\hline \multicolumn{2}{|c|}{ Dialysis } & 19,354 & 554 & $(2.9 \%)$ \\
\hline \multicolumn{2}{|c|}{ ASA Physical Status score III, IV, or V } & 19,334 & 15,627 & $(81 \%)$ \\
\hline \multirow[t]{6}{*}{ BMI } & Normal & 18,724 & 4,905 & $(26.2 \%)$ \\
\hline & Underweight & 18,724 & 498 & $(2.7 \%)$ \\
\hline & Overweight & 18,724 & 5,848 & $(31.2 \%)$ \\
\hline & Obesity class I & 18,724 & 3,943 & $(21.1 \%)$ \\
\hline & Obesity class II & 18,724 & 1,979 & $(10.6 \%)$ \\
\hline & Obesity class III & 18,724 & 1,551 & $(8.3 \%)$ \\
\hline \multicolumn{2}{|c|}{ Emergent } & 19,334 & 2,624 & $(13.6 \%)$ \\
\hline \multicolumn{2}{|c|}{ Postoperative re-intubation } & 19,355 & 85 & $(0.4 \%)$ \\
\hline \multicolumn{2}{|c|}{ 30-day mortality } & 19,355 & 452 & $(2.3 \%)$ \\
\hline \multicolumn{2}{|c|}{ Postoperative ventilator } & 19,355 & 2,769 & $(14.3 \%)$ \\
\hline \multicolumn{5}{|c|}{ Procedure type } \\
\hline \multicolumn{2}{|c|}{ General surgery } & 19,355 & 3,145 & $(16.2 \%)$ \\
\hline \multicolumn{2}{|c|}{ Gynecologic surgery } & 19,355 & 329 & $(1.7 \%)$ \\
\hline \multicolumn{2}{|c|}{ Head and neck surgery } & 19,355 & 2,339 & $(12.1 \%)$ \\
\hline \multicolumn{2}{|c|}{ Neurosurgery } & 19,355 & 4,676 & $(24.2 \%)$ \\
\hline \multicolumn{2}{|c|}{ Orthopedic surgery } & 19,355 & 1,441 & $(7.4 \%)$ \\
\hline \multicolumn{2}{|c|}{ Plastic surgery } & 19,355 & 231 & $(1.2 \%)$ \\
\hline \multicolumn{2}{|c|}{ Thoracic surgery } & 19,355 & 800 & $(4.1 \%)$ \\
\hline \multicolumn{2}{|c|}{ Transplant surgery } & 19,355 & 1,099 & $(5.7 \%)$ \\
\hline \multicolumn{2}{|c|}{ Urologic surgery } & 19,355 & 1,546 & $(8.0 \%)$ \\
\hline \multicolumn{2}{|c|}{ Vascular surgery } & 19,355 & 2,315 & $(12.0 \%)$ \\
\hline \multicolumn{2}{|c|}{ Other surgery } & 19,355 & 1,434 & $(7.4 \%)$ \\
\hline
\end{tabular}

\begin{tabular}{|c|c|c|c|c|c|}
\hline Demographics & $N$ & \multicolumn{2}{|c|}{ Mean (SD) } & \multicolumn{2}{|c|}{ Median [IQR] } \\
\hline & & & & & \\
\hline Age (yr) & 19,355 & 59 & $(16)$ & 61 & {$[51-70]$} \\
\hline Weight $(\mathrm{kg})$ & 19,086 & 86 & (24) & & \\
\hline Height $(\mathrm{cm})$ & 19,019 & 170 & $(11)$ & & \\
\hline \multicolumn{6}{|l|}{ Preoperative labs/vitals } \\
\hline Creatinine $\left(\mathrm{mg} \cdot \mathrm{dL}^{-1}\right)$ & 18,753 & 1.1 & $(1.0)$ & & \\
\hline Blood urea nitrogen $\left(\mathrm{mg} \cdot \mathrm{dL}^{-1}\right)$ & 18,646 & 20.1 & $(12.5)$ & & \\
\hline Creatinine clearance $\left(\mathrm{mL} \cdot \mathrm{min}^{-1}\right)$ & 18,490 & 104.7 & $(56.8)$ & & \\
\hline $\mathrm{SpO}_{2}(\%)$ & 18,842 & 97 & (2) & & \\
\hline Albumin $\left(\mathrm{g} \cdot \mathrm{dL}^{-1}\right)$ & 16,649 & 4.0 & $(0.7)$ & & \\
\hline \multicolumn{6}{|l|}{ Intraoperative variables } \\
\hline Case duration (min) & 19,354 & 357 & $(171)$ & & \\
\hline Time of ABG from anesthesia start (min)* & 19,355 & 73 & (26) & & \\
\hline \multicolumn{6}{|l|}{ Fluids $\dagger$} \\
\hline Total albumin (g) & 4,382 & 46 & (32) & 37 & {$[25-50]$} \\
\hline Hetastarch (mL) & 370 & 705 & (311) & 500 & [500-1000] \\
\hline
\end{tabular}


continued

\begin{tabular}{|c|c|c|c|c|c|}
\hline \multirow[b]{2}{*}{ Total crystalloid (mL) } & \multirow{2}{*}{$\frac{N}{19,355}$} & \multicolumn{2}{|c|}{ Mean (SD) } & \multicolumn{2}{|c|}{ Median [IQR] } \\
\hline & & 2,690 & $(1,524)$ & & \\
\hline Total volume blood products (mL) & 3,699 & 2,093 & $(4,815)$ & 700 & {$[350-1600]$} \\
\hline Total pRBC (mL) & 3,224 & 1,289 & $(2,264)$ & 700 & [350-1400] \\
\hline Total FFP (mL) & 1,184 & 1,885 & $(2860)$ & 825 & {$[550-2200]$} \\
\hline Total platelets (mL) & 830 & 676 & $(612)$ & 550 & {$[275-825]$} \\
\hline Total cryoprecipitate (mL) & 332 & 270 & (196) & 200 & {$[100-400]$} \\
\hline Estimated blood loss (mL) & 17,231 & 593 & $(1,546)$ & 200 & {$[100-500]$} \\
\hline \multicolumn{6}{|l|}{ Hemodynamics } \\
\hline Heart rate (beats $\cdot \mathrm{min}^{-1}$ ) & 19,179 & 72 & (16) & & \\
\hline Mean arterial pressure $(\mathrm{mm} \mathrm{Hg})$ & 18,179 & 79 & (14) & & \\
\hline \multicolumn{6}{|l|}{ Ventilator } \\
\hline Tidal volume $\left(\mathrm{mL} \cdot \mathrm{kg}^{-1}\right)$ & 18,296 & 7.7 & (1.6) & & \\
\hline Respiratory rate (breaths $\cdot \mathrm{min}^{-1}$ ) & 18,610 & 12 & (3) & & \\
\hline Minute ventilation $\left(\mathrm{L} \cdot \mathrm{min}^{-1}\right)$ & 18,532 & 5.8 & (1.4) & & \\
\hline Peak airway pressure $(\mathrm{mm} \mathrm{Hg})$ & 18,922 & 19 & (6) & & \\
\hline PEEP $(\mathrm{mm} \mathrm{Hg})$ & 18,842 & 5 & (2) & & \\
\hline End-tidal $\mathrm{CO}_{2}(\mathrm{~mm} \mathrm{Hg})$ & 19,355 & 34 & (4) & & \\
\hline Inspired oxygen percent (\%) & 18,900 & 61 & (23) & & \\
\hline \multicolumn{6}{|l|}{ Blood gas } \\
\hline $\mathrm{pH}$ & 19,293 & 7.41 & $(0.06)$ & & \\
\hline $\mathrm{PaO}_{2}(\mathrm{~mm} \mathrm{Hg})$ & 19,024 & 215 & $(108)$ & & \\
\hline $\mathrm{PaCO}_{2}(\mathrm{~mm} \mathrm{Hg})$ & 19,355 & 40 & (6) & & \\
\hline $\mathrm{PaCO}_{2}-\mathrm{PetCO}_{2}(\mathrm{~mm} \mathrm{Hg})$ & 19,355 & 6 & (5) & & \\
\hline Composite outcome & 19,355 & 3,006 & (16) & & \\
\hline
\end{tabular}

Body mass index (BMI) was subdivided into World Health Organization categories: underweight (BMI $\left.<18.5 \mathrm{~kg} \cdot \mathrm{m}^{-2}\right)$, normal $(\mathrm{BMI} 18.5-24.9$ $\mathrm{kg} \cdot \mathrm{m}^{-2}$ ) overweight (BMI 25-29.9 $\mathrm{kg} \cdot \mathrm{m}^{-2}$ ), obesity class I (BMI 30-34.9 $\mathrm{kg} \cdot \mathrm{m}^{-2}$ ), obesity class II (BMI $35.0-39.9 \mathrm{~kg} \cdot \mathrm{m}^{-2}$ ), and obesity class III $\left(\mathrm{BMI} \geq 40 \mathrm{~kg} \cdot \mathrm{m}^{-2}\right)$. Tidal volume calculated by dividing tidal volume by ideal body weight.

*The median [interquartile range] time of arterial blood gas from anesthesia start was 71 [54-91] min. †As most patients did not receive transfusions or colloid, numbers reflect only those patients who received a particular product with the corresponding means (standard deviations)/medians [interquartile ranges].

ASA = American Society of Anesthesiologists; BMI = body mass index; COPD = chronic obstructive pulmonary disease; FFP = fresh frozen plasma; IQR = interquartile range; $\mathrm{PaCO}_{2}=$ arterial partial pressure of carbon dioxide; $\mathrm{PaO}_{2}=$ arterial partial pressure of oxygen; $\mathrm{PEEP}=$ positive end expiratory pressure; $\mathrm{PetCO}_{2}=$ end-tidal partial pressure of carbon dioxide; $\mathrm{pRBC}=$ packed red blood cells; $\mathrm{SD}=\mathrm{standard}$ deviation; $\mathrm{SpO} 2=$ peripheral oxygen saturation .

composite outcome in a broad patient population of adults undergoing general anesthesia with arterial lines. Our results indicate that high intraoperative $\Delta \mathrm{CO}_{2}$ should not be ignored in patients undergoing general anesthesia. Additional studies are necessary to better understand the clinical utility of our results.

There are a few important limitations to this study. As a single-centre study, it might not be generalizable to other centres with different intraoperative ventilator strategies or practice surrounding $\mathrm{PaCO}_{2}$ measurement indications or timing. At our institution, $97.7 \%$ of patients who had an arterial line placed for their procedure had an ABG measured with a mean (SD) time from anesthesia start to
ABG measurement of 73 (26) min. This limits our findings to patients and procedures for which arterial lines are utilized and likely explains the wider $\Delta \mathrm{CO}_{2}$ found in this study compared with previous studies that excluded ASA III-V patients or patients with "respiratory or cardiac abnormalities." 35,36 Second, $\mathrm{PaCO}_{2}$ and $\mathrm{PetCO}_{2}$ are dynamic as patients undergo hours of anesthesia. The first $\mathrm{ABG}$ was selected to facilitate comparability of patients undergoing anesthesia as a baseline since many patients had only one ABG at the beginning of the case. Selecting the first ABG allowed for analysis of a large patient population; it also minimized bias. Nevertheless, this measure was more representative of the initial clinical 
Table 2 Univariable analysis for study variables

\begin{tabular}{|c|c|c|c|c|c|c|c|c|c|c|c|c|c|}
\hline & & & & \multicolumn{4}{|c|}{ No composite outcome } & \multicolumn{3}{|c|}{ Composite outcome } & \multirow{2}{*}{\multicolumn{2}{|c|}{$P$ value }} & \multirow[t]{2}{*}{ Cohen's $d$} \\
\hline & & & & $n$ & Total $N$ & & $\%)$ & $n$ & Total $N$ & $(\%)$ & & & \\
\hline \multicolumn{4}{|l|}{ Male } & 9,184 & 16,349 & & $56.2 \%)$ & 1,797 & 3,006 & $(59.8 \%)$ & & 0.001 & 0.07 \\
\hline \multirow{2}{*}{\multicolumn{4}{|c|}{$\begin{array}{l}\text { Preoperative supplemental } \mathrm{O}_{2} \\
\text { Comorbidities: }\end{array}$}} & 712 & 16,349 & & $4.4 \%)$ & 562 & 3,006 & $(18.7 \%)$ & & $<0.001$ & 0.46 \\
\hline & & & & & & & & & & & & & \\
\hline \multicolumn{4}{|c|}{ Current or former smoker } & 9,035 & 16,349 & & $55.3 \%)$ & 1,634 & 3,006 & $(54.4 \%)$ & & 0.36 & 0.02 \\
\hline \multicolumn{4}{|c|}{ Diagnosis of COPD } & 2,333 & 16,349 & & $14.3 \%)$ & 497 & 3,006 & $(16.5 \%)$ & & 0.002 & 0.06 \\
\hline \multicolumn{4}{|c|}{ Diagnosis of asthma } & 1,708 & 16,349 & & $10.4 \%)$ & 243 & 3,006 & $(8.1 \%)$ & & $<0.001$ & 0.08 \\
\hline \multicolumn{4}{|c|}{ Preoperative dialysis } & 355 & 16,349 & & $2.2 \%)$ & 199 & 3,005 & $(6.6 \%)$ & & $<0.001$ & 0.22 \\
\hline \multirow[t]{6}{*}{ BMI } & \multicolumn{3}{|l|}{ Normal } & 4,154 & 15,926 & & $26.1 \%)$ & 751 & 2,798 & $(26.8 \%)$ & & $<0.001$ & 0.02 \\
\hline & \multicolumn{3}{|c|}{ Underweight } & 387 & 15,926 & & $2.4 \%)$ & 111 & 2,798 & $(4.0 \%)$ & & & 0.09 \\
\hline & \multicolumn{3}{|c|}{ Overweight } & 5,031 & 15,926 & & $31.6 \%)$ & 817 & 2,798 & $(29.2 \%)$ & & & 0.05 \\
\hline & \multicolumn{3}{|c|}{ Obesity class I } & 3,396 & 15,926 & & $21.3 \%)$ & 547 & 2,798 & $(19.5 \%)$ & & & 0.04 \\
\hline & \multicolumn{3}{|c|}{ Obesity class II } & 1,681 & 15,926 & & $10.6 \%)$ & 298 & 2,798 & $(10.7 \%)$ & & & $<0.01$ \\
\hline & \multicolumn{3}{|c|}{ Obesity class III } & 1,277 & 15,926 & & $8.0 \%)$ & 274 & 2,798 & $(9.8 \%)$ & & & 0.06 \\
\hline \multicolumn{4}{|c|}{ ASA Physical Status score III, IV, or V } & 12,946 & 16,335 & & $79.3 \%)$ & 2,681 & 2,999 & $(89.4 \%)$ & & $<0.001$ & 0.28 \\
\hline \multicolumn{4}{|c|}{ Emergent } & 1,295 & 16,335 & & $7.9 \%)$ & 1,329 & 2,999 & $(44.3 \%)$ & & $<0.001$ & 0.91 \\
\hline \multicolumn{14}{|c|}{ Procedure type } \\
\hline \multicolumn{4}{|c|}{ General surgery } & 2,470 & 16,349 & & $15.1 \%)$ & 675 & 3,006 & $(2.5 \%)$ & & $<0.001$ & 0.19 \\
\hline Gynec & gery & & & 284 & 16,349 & & $1.7 \%)$ & 45 & 3,006 & $(1.5 \%)$ & & 0.39 & 0.02 \\
\hline Head & urgery & & & 1,944 & 16,349 & & $11.9 \%)$ & 395 & 3,006 & $(13.1 \%)$ & & 0.06 & 0.04 \\
\hline Neuro & & & & 4,267 & 16,349 & & $26.1 \%)$ & 409 & 3,006 & $(13.6 \%)$ & & $<0.001$ & 0.32 \\
\hline Orthol & & & & 1,294 & 16,349 & & $7.9 \%)$ & 147 & 3,006 & $(4.9 \%)$ & & $<0.001$ & 0.12 \\
\hline Plastic & & & & 201 & 16,349 & & $1.2 \%)$ & 30 & 3,006 & $(1.0 \%)$ & & 0.32 & 0.02 \\
\hline Thora & & & & 726 & 16,349 & & $4.4 \%)$ & 74 & 3,006 & $(2.5 \%)$ & & $<0.001$ & 0.11 \\
\hline Trans! & & & & 626 & 16,349 & & $3.8 \%)$ & 473 & 3,006 & $(15.7 \%)$ & & $<0.001$ & 0.41 \\
\hline Urolos & & & & 1,432 & 16,349 & & $8.8 \%)$ & 114 & 3,006 & $(3.8 \%)$ & & $<0.001$ & 0.21 \\
\hline Vascu & & & & 2,020 & 16,349 & & $12.4 \%)$ & 295 & 3,006 & $(9.8 \%)$ & & $<0.001$ & 0.08 \\
\hline Other & & & & 1,085 & 16,349 & & $6.6 \%)$ & 349 & 3,006 & $(11.6 \%)$ & & $<0.001$ & 0.17 \\
\hline & & No con & osi & outcome & & & Compc & ite outcol & & & & & \\
\hline & & $\begin{array}{l}\text { Mean } \\
(\mathrm{SD})\end{array}$ & & an [IQR] & & $n$ & $\begin{array}{l}\text { Mean } \\
\text { (SD) }\end{array}$ & Median & [IQR] & & $n$ & $P$ value ${ }^{*}$ & $\begin{array}{l}\text { Cohen's } \\
d\end{array}$ \\
\hline Demo & & & & & & & & & & & & & \\
\hline Age ( & & 59.4 & & & & 16,349 & 959.1 & $(15.2)$ & & & 3,006 & 50.39 & 0.02 \\
\hline Weigh & & 85.3 & & & & 16,215 & $\begin{array}{ll}5 & 86.4\end{array}$ & (26.2) & & & 2,871 & 0.03 & 0.05 \\
\hline Heigh & & 170 & & & & 16,120 & $\begin{array}{ll}0 & 170.4\end{array}$ & (11.2) & & & 2,899 & 0.04 & 0.04 \\
\hline Preop & bs/vitals & & & & & & & & & & & & \\
\hline $\begin{array}{l}\text { Preope } \\
1 \text { ) }\end{array}$ & $\left(\mathrm{mg} \cdot \mathrm{dL}^{-}\right.$ & 1.0 & & & & 15,811 & $\begin{array}{ll}1 & 1.3\end{array}$ & (1.2) & & & 2,942 & $<0.001$ & 0.24 \\
\hline $\begin{array}{l}\text { Preope } \\
\quad(\mathrm{mg}\end{array}$ & & 19.2 & & & & 15,723 & $\begin{array}{ll}3 & 25.2\end{array}$ & $(18.2)$ & & & 2,923 & $<0.001$ & 0.24 \\
\hline $\begin{aligned} \text { Creati } \\
\quad(\mathrm{mL}\end{aligned}$ & ance & 105.3 & & & & 15,682 & 2101.5 & $(68.3)$ & & & 2,808 & 0.006 & 0.06 \\
\hline $\begin{array}{l}\text { Preope } \\
(\mathrm{g} \cdot \mathrm{d}\end{array}$ & umin & 4.1 & & & & 13,946 & 63.5 & $(0.8)$ & & & 2,703 & $<0.001$ & 0.90 \\
\hline Preope & $\mathrm{O}_{2}(\%)$ & 96.8 & & & & 16,033 & 396.5 & (2.6) & & & 2,809 & $<0.001$ & 0.10 \\
\hline $\begin{array}{r}\text { Intrac } \\
\text { var }\end{array}$ & & & & & & & & & & & & & \\
\hline Case $c$ & $\min )$ & 350.3 & & & & 16,348 & $\begin{array}{ll}8 & 390.8\end{array}$ & (220.6) & & & 3,006 & $<0.001$ & 0.21 \\
\hline
\end{tabular}


continued

\begin{tabular}{|c|c|c|c|c|c|c|c|c|c|c|c|c|}
\hline & \multicolumn{5}{|c|}{ No composite outcome } & \multicolumn{5}{|c|}{ Composite outcome } & \multirow[b]{2}{*}{$P$ value ${ }^{*}$} & \multirow[b]{2}{*}{$\begin{array}{l}\text { Cohen's } \\
d\end{array}$} \\
\hline & $\begin{array}{l}\text { Mean } \\
\text { (SD) }\end{array}$ & Median & $n[I Q]$ & & $n$ & $\begin{array}{l}\text { Mean } \\
\text { (SD) }\end{array}$ & Median & [IQR] & & $n$ & & \\
\hline $\begin{array}{l}\text { Time of ABG from } \\
\text { anesthesia } \\
\text { start (min) }\end{array}$ & 73.4 & $(26.1)$ & & & 16,349 & 70.9 & $(27.1)$ & & & 3,006 & $<0.001$ & 0.09 \\
\hline \multicolumn{13}{|l|}{ Fluids§ } \\
\hline Total crystalloid (mL) & 2,651 & $(1,394)$ & & & 16,349 & 2,904 & $(2,087)$ & & & 3,006 & $0.28 t$ & 0.14 \\
\hline Total albumin (g) & 41.3 & $(24.8)$ & 25 & {$[25-25]$} & 3,196 & 59.5 & $(44.4)$ & 50 & {$[50-75]$} & 1,186 & $<0.001 t$ & 0.49 \\
\hline Hetastarch $(\mathrm{mL})$ & 689 & $(296)$ & 500 & [500-1000] & 307 & 780 & $(364)$ & 800 & {$[500-1,000]$} & 63 & $0.41 \ddagger$ & 0.03 \\
\hline $\begin{array}{l}\text { Total volume blood products } \\
\quad(\mathrm{mL})\end{array}$ & 861 & $(893)$ & 700 & {$[350-1050]$} & 2,221 & 3,942 & $(7,151)$ & 1,400 & {$[700-4,213]$} & 1,478 & $<0.001 t$ & 0.48 \\
\hline Total pRBC (mL) & 727 & $(518)$ & 700 & {$[350-700]$} & 1,884 & 2,080 & $(3,300)$ & 1,050 & {$[700-2,100]$} & 1,340 & $<0.001 \ddagger$ & 0.49 \\
\hline Total FFP (mL) & 734 & $(649)$ & 550 & {$[275-825]$} & 395 & 2,462 & $(3,328)$ & 1,340 & {$[550-3,300]$} & 789 & $<0.001 \ddagger$ & 0.44 \\
\hline Total platelets (mL) & 446 & $(315)$ & 275 & {$[275-550]$} & 272 & 787 & $(686)$ & 550 & {$[275-1,100]$} & 558 & $<0.001 \ddagger$ & 0.46 \\
\hline $\begin{array}{l}\text { Total cryoprecipitate } \\
\qquad(\mathrm{mL})\end{array}$ & 174 & (87) & 200 & [100-200] & 30 & 280 & (201) & 200 & {$[200-400]$} & 302 & $<0.001 \ddagger$ & 0.37 \\
\hline $\begin{array}{l}\text { Estimated blood loss } \\
\quad(\mathrm{mL})\end{array}$ & 394 & $(584)$ & 200 & {$[75-400]$} & 14,755 & 1,776 & $(3,601)$ & 450 & [100-1706] & 2,476 & $<0.001 \ddagger$ & 0.54 \\
\hline \multicolumn{13}{|l|}{ Hemodynamics $\dagger$} \\
\hline Heart rate (beats. $\min ^{-1}$ ) & 71 & (15) & & & 16,193 & 81 & (20) & & & 2,986 & $<0.001$ & 0.58 \\
\hline $\begin{array}{l}\text { Mean arterial pressure } \\
(\mathrm{mm} \mathrm{Hg})\end{array}$ & 79 & (14) & & & 15,366 & 76 & (15) & & & 2,813 & $<0.001$ & 0.20 \\
\hline \multicolumn{13}{|l|}{ Ventilator $\dagger$} \\
\hline Tidal volume $\left(\mathrm{mL} \cdot \mathrm{kg}^{-1}\right)$ & 7.7 & (1.6) & & & 15,507 & 7.5 & (1.7) & & & 2,789 & $<0.001$ & 0.12 \\
\hline $\begin{array}{l}\text { Respiratory rate } \\
\quad\left(\text { breaths } \cdot \min ^{-1}\right)\end{array}$ & 12 & (3) & & & 15,720 & 12 & (3) & & & 2,890 & $<0.001$ & 0.22 \\
\hline $\begin{array}{l}\text { Minute ventilation } \\
\left(\mathrm{L} \cdot \mathrm{min}^{-1}\right)\end{array}$ & 5.7 & (1.4) & & & 15,662 & 5.9 & (1.6) & & & 2,870 & $<0.001$ & 0.11 \\
\hline $\begin{array}{l}\text { Peak airway pressure } \\
(\mathrm{mm} \mathrm{Hg})\end{array}$ & 18.5 & (5.6) & & & 16,027 & 20.5 & $(6.0)$ & & & 2,895 & $<0.001$ & 0.34 \\
\hline PEEP (mm Hg) & 4.8 & $(1.8)$ & & & 15,954 & 5.1 & (2.1) & & & 2,888 & $<0.001$ & 0.14 \\
\hline End-tidal $\mathrm{CO}_{2}(\mathrm{~mm} \mathrm{Hg})$ & 34.4 & (3.8) & & & 16,349 & 34.8 & $(4.8)$ & & & 3,006 & $<0.001$ & 0.11 \\
\hline Inspired oxygen (\%) & 60 & (22) & & & 16,010 & 70 & (24) & & & 2,890 & $<0.001$ & 0.41 \\
\hline \multicolumn{13}{|l|}{ Blood gas } \\
\hline $\mathrm{pH}$ & 7.4 & $(0.1)$ & & & 16,298 & 7.4 & $(0.1)$ & & & 2,995 & $<0.001$ & 0.41 \\
\hline $\mathrm{PaO}_{2}(\mathrm{~mm} \mathrm{Hg})$ & 215.0 & $(107.0)$ & & & 16,061 & 217.5 & $(113.2)$ & & & 2,963 & 0.28 & 0.02 \\
\hline $\mathrm{PaCO}_{2}(\mathrm{~mm} \mathrm{Hg})$ & 40.1 & (5.7) & & & 16,349 & 40.9 & $(6.7)$ & & & 3,006 & $<0.001$ & 0.13 \\
\hline $\begin{array}{l}\mathrm{PaCO}_{2}-\mathrm{PetCO}_{2}(\mathrm{~mm} \\
\mathrm{Hg})\end{array}$ & 5.7 & (4.5) & & & 16,349 & 6.1 & (5.3) & & & 3,006 & 0.002 & 0.07 \\
\hline
\end{tabular}

Body mass index (BMI) was subdivided into World Health Organization categories: underweight (BMI $<18.5 \mathrm{~kg} \cdot \mathrm{m}^{-2}$ ), normal (BMI $18.5-24.9$ $\mathrm{kg} \cdot \mathrm{m}^{-2}$ ), overweight (BMI 25-29.9 $\mathrm{kg} \cdot \mathrm{m}^{-2}$ ), obesity class I (BMI 30-34.9 $\mathrm{kg} \cdot \mathrm{m}^{-2}$ ), obesity class II (BMI $35.0-39.9 \mathrm{~kg} \cdot \mathrm{m}^{-2}$ ), and obesity class III $\left(\mathrm{BMI} \geq 40 \mathrm{~kg} \cdot \mathrm{m}^{-2}\right)$.

${ }^{*} t$ test $P$ value unless otherwise indicated; $\dagger$ Median values from the $10 \mathrm{~min}$ epoch surrounding arterial blood gas analysis were utilized in calculation; $\$$ Mann-Whitney U test $P$ value. $\S$ As most patients did not receive transfusions or colloid, numbers reflect only those patients who received a particular product with the corresponding means (standard deviations)/medians [interquartile ranges].

$\mathrm{ABG}=$ arterial blood gas; $\mathrm{ASA}=$ American Society of Anesthesiologist $; \mathrm{BMI}=$ body mass index $; \mathrm{BUN}=$ blood urea nitrogen COPD $=$ chronic obstructive pulmonary disease; $\mathrm{Cr}=$ creatinine; $\mathrm{FFP}=$ fresh frozen plasma; $\mathrm{IQR}=$ interquartile range; $\mathrm{PaCO}_{2}=$ arterial partial pressure of carbon dioxide; $\mathrm{PaO}_{2}=$ arterial partial pressure of oxygen; $\mathrm{PEEP}=$ positive end expiratory pressure; $\mathrm{PetCO}_{2}=$ end-tidal partial pressure of carbon dioxide; $\mathrm{pRBC}=$ packed red blood cells; $\mathrm{SD}=$ standard deviation; $\mathrm{SpO} 2=$ peripheral oxygen saturation. 
Table 3 Multivariable regression for composite outcome

\begin{tabular}{|c|c|c|c|}
\hline & Odds ratio & $(95 \% \mathrm{CI})$ & $P$ value \\
\hline (Intercept) & 0.01 & $(0.004$ to 0.024$)$ & $<0.001$ \\
\hline \multicolumn{4}{|l|}{ Preoperative variables } \\
\hline Emergent procedure & 5.45 & (4.69 to 6.33$)$ & $<0.001$ \\
\hline Age (yr) & 1.01 & (1.00 to 1.01$)$ & 0.007 \\
\hline Male & 1.03 & $(0.90$ to 1.17$)$ & 0.71 \\
\hline Supplemental $\mathrm{O}_{2}$ & 2.37 & $(1.97$ to 2.84$)$ & $<0.001$ \\
\hline Current or former smoker & 0.91 & $(0.81$ to 1.03$)$ & 0.15 \\
\hline COPD & 1.16 & (0.99 to 1.36$)$ & 0.06 \\
\hline ASA Physical Status III-IV or V & 1.21 & (1.01 to 1.45$)$ & 0.04 \\
\hline Asthma & 0.75 & $(0.61$ to 0.93$)$ & 0.007 \\
\hline Preoperative dialysis & 1.45 & (1.08 to 1.95$)$ & 0.01 \\
\hline \multicolumn{4}{|l|}{ BMI category } \\
\hline Normal & 1 & & \\
\hline Underweight & 1.03 & $(0.74$ to 1.44$)$ & 0.85 \\
\hline Overweight & 1.01 & $(0.87$ to 1.18$)$ & 0.89 \\
\hline Obesity class I & 1.14 & $(0.96$ to 1.35$)$ & 0.15 \\
\hline Obesity class II & 1.12 & $(0.90$ to 1.39$)$ & 0.32 \\
\hline Obesity class III & 1.34 & $(1.06$ to 1.71$)$ & 0.02 \\
\hline \multicolumn{4}{|l|}{ Procedure type } \\
\hline Head and neck + plastic surgery & 1.32 & $(1.09$ to 1.60$)$ & 0.004 \\
\hline Neurosurgery & 0.57 & $(0.48$ to 0.68$)$ & $<0.001$ \\
\hline Orthopedic surgery & 0.58 & $(0.45$ to 0.75$)$ & $<0.001$ \\
\hline Urologic surgery & 0.62 & $(0.48$ to 0.80$)$ & $<0.001$ \\
\hline General/gynecologic/thoracic/transplant surgery & 0.69 & $(0.57$ to 0.85$)$ & $<0.001$ \\
\hline Other surgery & 1.56 & (1.21 to 2.03$)$ & 0.001 \\
\hline Creatinine clearance $\left(\mathrm{mL} \cdot \mathrm{min}^{-1}\right)$ & 1.00 & $(1.00$ to 1.00$)$ & 0.001 \\
\hline Preoperative albumin $\left(\mathrm{g} \cdot \mathrm{dL}^{-1}\right)$ & 0.53 & $(0.48$ to 0.58$)$ & $<0.001$ \\
\hline \multicolumn{4}{|l|}{ Intraoperative variables } \\
\hline Albumin transfused $(\mathrm{g})$ & 1.01 & $(1.01$ to 1.01$)$ & $<0.001$ \\
\hline Case duration (min) & 1.29 & $(1.24$ to 1.34$)$ & $<0.001$ \\
\hline Total volume blood products (mL) & 1.81 & (1.68 to 1.94$)$ & $<0.001$ \\
\hline Inspired oxygen $(\%)$ & 1.01 & (1.01 to 1.02$)$ & $<0.001$ \\
\hline Tidal volume $\left(\mathrm{mL} \cdot \mathrm{kg}^{-1}\right)$ & 1.05 & (1.00 to 1.09$)$ & 0.046 \\
\hline Respiratory rate (breaths $\cdot \min ^{-1}$ ) & 1.07 & (1.05 to 1.10$)$ & $<0.001$ \\
\hline Mean arterial pressure $(\mathrm{mm} \mathrm{Hg})$ & 1.0 & (0.99 to 1.00$)$ & 0.243 \\
\hline Heart rate (beats $\cdot \mathrm{min}^{-1}$ ) & 1.02 & (1.01 to 1.02$)$ & $<0.001$ \\
\hline $\mathrm{PaCO}_{2}-\mathrm{PetCO}_{2}(5 \mathrm{~mm} \mathrm{Hg})$ & 1.20 & (1.12 to 1.28$)$ & $<0.001$ \\
\hline
\end{tabular}

BMI was subdivided into World Health Organization categories: underweight $\left(\mathrm{BMI}<18.5 \mathrm{~kg} \cdot \mathrm{m}^{-2}\right)$, normal $\left(\mathrm{BMI} 18.5-24.9 \mathrm{~kg} \cdot \mathrm{m}^{-2}\right)$, overweight (BMI $25-29.9 \mathrm{~kg} \cdot \mathrm{m}^{-2}$ ), obesity class I (BMI 30-34.9 $\mathrm{kg}^{2}$ ), obesity class II (BMI $35.0-39.9 \mathrm{~kg} \cdot \mathrm{m}^{-2}$ ), and obesity class III (BMI $\geq 40 \mathrm{~kg} \cdot \mathrm{m}^{-2}$ ). Akaike Information Criteria $=8356.444$, Bayes Information Criteria $=8599.658,-2 \operatorname{logLikelihood}=928292.444$, and C statistic $=0.87(95 \% \mathrm{CI}$, 0.86 to 0.88 ).

ASA = American Society of Anesthesiologists; $\mathrm{BMI}=$ body mass index; CI = confidence interval; COPD = chronic obstructive pulmonary disease; $\mathrm{PaCO}_{2}=$ arterial partial pressure of carbon dioxide; $\mathrm{PetCO}_{2}=$ end-tidal partial pressure of carbon dioxide.

condition, rather than the final clinical condition, of patients undergoing anesthesia. Furthermore, we did not evaluate whether $\Delta \mathrm{CO}_{2}$ changes over the course of surgery and how that is associated with outcomes. Evaluating these changes and whether they can predict outcome needs further investigation.

Previous studies have investigated risk factors for postoperative respiratory failure and have developed 
Fig. 2 Predicted risk of pulmonary complications for different $\Delta \mathrm{CO}_{2}$ values overlaid on a histogram showing the distribution of $\Delta \mathrm{CO}_{2}$ values included in this study. The $\Delta \mathrm{CO}_{2}$ range spanned values of $10 \mathrm{~mm} \mathrm{Hg}$ to $30 \mathrm{~mm} \mathrm{Hg}$ with most being between $0 \mathrm{~mm} \mathrm{Hg}$ and $10 \mathrm{~mm} \mathrm{Hg}$. After adjusting for all factors in the multivariable model, a curvilinear relationship can be seen between $\Delta \mathrm{CO}_{2}$ values and postoperative pulmonary complications with higher $\Delta \mathrm{CO}_{2}$ values predicting greater risk. $\Delta \mathrm{CO}_{2}=$ difference between arterial and end-tidal partial pressure of carbon dioxide.

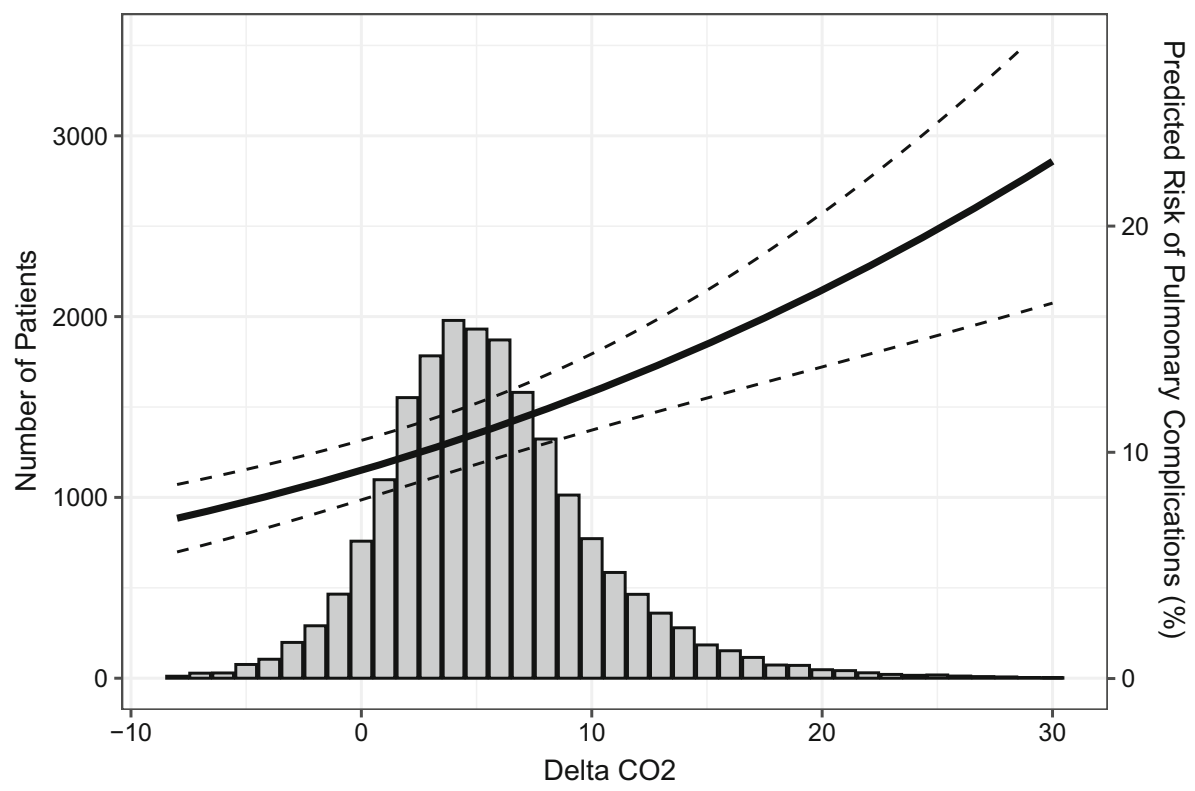

clinically predictive models. ${ }^{37}$ Some of these clinically significant variables were not included in our analysis because they were not collected in our EHR. For example, New York Heart Association heart failure class has been shown to be a risk factor for postoperative pulmonary complications, ${ }^{37}$ but this variable is not present in our anesthesia preoperative history. Where a previous study found that lower preoperative $\mathrm{SpO}_{2}$ levels were associated with postoperative pulmonary complications, ${ }^{38}$ our patients with low values had been placed on supplemental oxygen. Additionally, risk scores developed on a more general surgical population may not be applicable to our unique patient population, specifically patients with an arterial catheter who underwent non-cardiac surgery.

Despite these limitations, our findings support the need for future research on the relationship between $\Delta \mathrm{CO}_{2}$ and postoperative adverse events. This study was retrospective and must be evaluated prospectively in patients undergoing non-cardiac surgery with a study design to address some of the limitations encountered in this patient population. Next, additional patient populations, such as those undergoing anesthesia without mechanical ventilation, pediatric patients, or those undergoing one-lung ventilation should be evaluated. Patients who require one-lung ventilation might represent a specific population risk of ventilation efficiency and where $\Delta \mathrm{CO}_{2}$ might have clinical predictive value.

In addition to evaluating the $\Delta \mathrm{CO}_{2}$ in other patient populations, additional research is needed to determine if specific therapies are beneficial when elevated $\Delta \mathrm{CO}_{2}$ is detected. For example, one animal study of ARDS found that the PEEP value that minimized capnography-measured $\mathrm{VD}_{\text {alv }}$ also maximized $\mathrm{CO}$ and mixed venous oxygen saturation. ${ }^{39}$ Further study is needed to determine if individualizing care, through ventilator adjustments or manipulation of hemodynamics, based on minimizing $\Delta \mathrm{CO}_{2}$ reduces adverse events.

\section{Conclusions}

Our study shows an independent association between increases in $\Delta \mathrm{CO}_{2}$ and a composite outcome of reintubation, postoperative mechanical ventilation, or 30-day mortality in patients undergoing non-cardiac surgery. Future research is needed to determine if the $\Delta \mathrm{CO}_{2}$ can be used for risk stratification or as a target for the optimization of intraoperative ventilator and hemodynamic management.

Author contributions Ryan Davis, Milo Engoren, and Michael Maile contributed to all aspects of this manuscript, including study conception and design; acquisition, analysis, and interpretation of data; and drafting the article. Elizabeth Jewell contributed to all aspects of this manuscript, including study design; acquisition, analysis, and interpretation of data; and drafting the article

Disclosure Michael D. Maile was supported by KL2TR002241.

Conflicts of interest None.

Funding None.

Editorial responsibility This submission was handled by Dr. Sheila Riazi, Associate Editor, Canadian Journal of Anesthesia/Journal canadien d'anesthésie. 


\section{References}

1. Khuri SF, Henderson WG, DePalma RG, et al. Determinants of long-term survival after major surgery and the adverse effect of postoperative complications. Ann Surg 2005; 242: 326-41.

2. Smetana $G W$. Postoperative pulmonary complications: an update on risk assessment and reduction. Cleve Clin J Med 2009; 76 Suppl 4: S60-5.

3. Nafiu OO, Ramachandran SK, Ackwerh $R$, Tremper $K K$, Campbell DA Jr, Stanley JC. Factors associated with and consequences of unplanned post-operative intubation in elderly vascular and general surgery patients. Eur J Anaesthesiol 2011; 28: $220-4$.

4. Ramachandran SK, Nafiu OO, Ghaferi A, Tremper KK, Shanks A, Kheterpal $S$. Independent predictors and outcomes of unanticipated early postoperative tracheal intubation after nonemergent, noncardiac surgery. Anesthesiology 2011; 115: 44-53.

5. Ladha K, Vidal Melo MF, McLean DJ, et al. Intraoperative protective mechanical ventilation and risk of postoperative respiratory complications: hospital based registry study. BMJ 2015; DOI: https://doi.org/10.1136/bmj.h3646.

6. Futier E, Constantin JM, Paugam-Burtz C, et al. A trial of intraoperative low-tidal-volume ventilation in abdominal surgery. N Engl J Med 2013; 369: 428-37.

7. Severgnini $P$, Selmo $G$, Lanza $C$, et al. Protective mechanical ventilation during general anesthesia for open abdominal surgery improves postoperative pulmonary function. Anesthesiology 2013; 118: 1307-21.

8. Fernandez-Perez ER, Sprung J, Afessa B, et al. Intraoperative ventilator settings and acute lung injury after elective surgery: a nested case control study. Thorax 2009; 64: 121-7.

9. Nassar BS, Schmidt GA. Estimating arterial partial pressure of carbon dioxide in ventilated patients: how valid are surrogate measures? Ann Am Thorac Soc 2017; 14: 1005-14.

10. Nunn JF. Nunn's Applied Respiratory Physiology, 2nd ed. London: Butterworths; 1977: 220-2.

11. Luostarinen T, Dilmen OK, Niiya T, Niemi T. Effect of arterial blood pressure on the arterial to end-tidal carbon dioxide difference during anesthesia induction in patients scheduled for craniotomy. J Neurosurg Anesthesiol 2010; 22: 303-8.

12. Casati A, Salvo I, Torri G, Calderini E. Arterial to end-tidal carbon dioxide gradient and physiological dead space monitoring during general anaesthesia: effects of patients' position. Minerva Anestesiol 1997; 63: 177-82.

13. Domsky M, Wilson RF, Heins J. Intraoperative end-tidal carbon dioxide values and derived calculations correlated with outcome: prognosis and capnography. Crit Care Med 1995; 23: 1497-503.

14. Nuckton TJ, Alonso JA, Kallet RH, et al. Pulmonary dead-space fraction as a risk factor for death in the acute respiratory distress syndrome. N Engl J Med 2002; 346: 1281-6.

15. Cepkova $M$, Kapur $V$, Ren $X$, et al. Pulmonary dead space fraction and pulmonary artery systolic pressure as early predictors of clinical outcome in acute lung injury. Chest 2007; 132: 836-42.

16. Raurich JM, Vilar M, Colomar A, et al. Prognostic value of the pulmonary dead-space fraction during the early and intermediate phases of acute respiratory distress syndrome. Respir Care 2010; 55: 282-7.

17. Maisch S, Reissmann H, Fuellekrug B, et al. Compliance and dead space fraction indicate an optimal level of positive endexpiratory pressure after recruitment in anesthetized patients. Anesth Analg 2008; 106: 175-81.

18. Tusman G, Suarez-Sipmann F, Bohm SH, et al. Monitoring dead space during recruitment and PEEP titration in an experimental model. Intensive Care Med 2006; 32: 1863-71.
19. Fengmei G, Jin C, Songqiao L, Congshan Y, Yi Y. Dead space fraction changes during PEEP titration following lung recruitment in patients with ARDS. Respir Care 2012; 57: 1578-85.

20. Nunn JF, Hill DW. Respiratory dead space and arterial to endtidal carbon dioxide tension difference in anesthetized man. J Appl Physiol 1960; 15: 383-9.

21. Hardman JG, Aitkenhead AR. Estimating alveolar dead space from the arterial to end-tidal $\mathrm{CO}(2)$ gradient: a modeling analysis. Anesth Analg 2003; 97: 1846-51.

22. Grenier B, Verchere E, Mesli A, et al. Capnography monitoring during neurosurgery: reliability in relation to various intraoperative positions. Anesth Analg 1999; 88: 43-8.

23. McDonald MJ, Montgomery VL, Cerrito PB, Parrish CJ, Boland $K A$, Sullivan JE. Comparison of end-tidal $\mathrm{CO} 2$ and $\mathrm{Paco} 2$ in children receiving mechanical ventilation. Pediatr Crit Care Med 2002; 3: 244-9.

24. Short JA, Paris ST, Booker PD, Fletcher R. Arterial to end-tidal carbon dioxide tension difference in children with congenital heart disease. Br J Anaesth 2001; 86: 349-53.

25. Russell GB, Graybeal JM. Reliability of the arterial to end-tidal carbon dioxide gradient in mechanically ventilated patients with multisystem trauma. J Trauma 1994; 36: 317-22.

26. Kerr ME, Zempsky J, Sereika S, Orndoff P, Rudy EB. Relationship between arterial carbon dioxide and end-tidal carbon dioxide in mechanically ventilated adults with severe head trauma. Crit Care Med 1996; 24: 785-90.

27. Tobias JD, Meyer DJ. Noninvasive monitoring of carbon dioxide during respiratory failure in toddlers and infants: end-tidal versus transcutaneous carbon dioxide. Anesth Analg 1997; 85: 55-8.

28. Berkenbosch JW, Lam J, Burd RS, Tobias JD. Noninvasive monitoring of carbon dioxide during mechanical ventilation in older children: end-tidal versus transcutaneous techniques. Anesth Analg 2001; 92: 1427-31.

29. Tyburski JG, Carlin AM, Harvey EH, Steffes C, Wilson RF. Endtidal $\mathrm{CO} 2$-arterial $\mathrm{CO} 2$ differences: a useful intraoperative mortality marker in trauma surgery. J Trauma 2003; 55: 892-6.

30. Plantier L, Cazes A, Dinh-Xuan AT, Bancal C, Marchand-Adam $S$, Crestani B. Physiology of the lung in idiopathic pulmonary fibrosis. Eur Respir Rev 2018; DOI: https://doi.org/10.1183/ 16000617.0062-2017.

31. McSwain SD, Hamel DS, Smith PB, et al. End-tidal and arterial carbon dioxide measurements correlate across all levels of physiologic dead space. Respir Care 2010; 55: 288-93.

32. Yousuf T, Brinton T, Murtaza G, et al. Establishing a gradient between partial pressure of arterial carbon dioxide and end-tidal carbon dioxide in patients with acute respiratory distress syndrome. J Investig Med 2017; 65: 338-41.

33. Morales-Quinteros L, Schultz MJ, Bringue J, et al. Estimated dead space fraction and the ventilatory ratio are associated with mortality in early ARDS. Ann Intensive Care 2019; DOI: https:// doi.org/10.1186/s13613-019-0601-0.

34. Moon SW, Lee SW, Choi SH, Hong YS, Kim SJ, Kim NH. Arterial minus end-tidal $\mathrm{CO} 2$ as a prognostic factor of hospital survival in patients resuscitated from cardiac arrest. Resuscitation 2007; 72 : 219-25.

35. Mahajan S, Chauhan R, Luthra A, Bala I, Bharti N, Sharma A. Evaluation of arterial to end-tidal carbon dioxide pressure differences during laparoscopic renal surgery in the lateral decubitus position. Anesth Essays Res 2019; 13: 583-8.

36. Shankar KB, Moseley H, Kumar Y, Vemula V, Krishnan A. Arterial to end-tidal carbon dioxide tension difference during anaesthesia for tubal ligation. Anaesthesia 1987; 42: 482-6.

37. Canet J, Sabate S, Mazo V, et al. Development and validation of a score to predict postoperative respiratory failure in a multicentre 
European cohort: a prospective, observational study. Eur J Anaesthesiol 2015; 32: 458-70.

38. Gupta S, Fernandes RJ, Rao JS, Dhanpal R. Perioperative risk factors for pulmonary complications after non-cardiac surgery. J Anaesthesiol Clin Pharmacol 2020; 36: 88-93.
39. Yang $Y$, Huang $Y$, Tang $R$, et al. Optimization of positive endexpiratory pressure by volumetric capnography variables in lavage-induced acute lung injury. Respiration 2014; 87: 75-83.

Publisher's Note Springer Nature remains neutral with regard to jurisdictional claims in published maps and institutional affiliations. 